\title{
Environmental Education through Research-Based Project Approach for Early Childhood Education
}

\author{
Ocih Setiasih, Heny Djoehaeni, Asep Deni Gustiana, Leli Kurniawati \\ Early Childhood Teacher Training Program, Faculty of Education - Universitas Pendidikan Indonesia \\ Corresponding e-mail: setiasih@upi.edu
}

\begin{abstract}
Environmental problems are frequently caused by a lack of caring and awareness on human's part. Education has made efforts to play an important role to generate people's awareness and caring towards betterments of environments. Environmental education has to be initiated to set on children in their early age through appropriate approach with developmental characteristics and the principles of learning for children. Various approaches and strategies are the teachers to choose to facilitate the learning to gain environmental awareness on the children's part. Research-based project approach is one of the appropriate approaches to implement environmental education. The aim of the present article writing is to discuss environmental education through research-based project approach. The discussion is focused on environmental education concepts and research-based project approach set for early childhood education.
\end{abstract}

Keywords: environmental education, early childhood, research-based project approach

\section{INTRODUCTION}

Problems having to do with environments demand closer examination from various sectors including education ties. Bezzina (2006) emphasizes that environmental crises prove to be national concerns and natural issues as well. Accordingly, steps to be taken are necessary in that educational sectors have every reason to overcome problems arise.

Decreasing natural resources and the environmental problems trigger one of the thoughts leading to concerns and awareness of the importance of environmental education at every level of educating people.

Environmental education must be generated since children in their early age through meaningful and pleasing learning experiences. Tilbury, D. (1994) puts forward that "Such experience play a critical role in shaping lifelong attitudes, value, and patterns of behavior towards natural environment". The importance of environmental education should be implemented in earlier age based on two main premises. The first premise, is that children must develop a sense of respect and caring for the natural environment during their first few years of life or be at risk for never developing such attitudes. The second premise is that positive interactions with the natural environment is an important part of healthy child development (Wilson, 1996). This means that environmental education grown since children are in their early age is expected to bring with it a potential to develop the children's positive attitudes towards environment. Sutrisno et.al. (2005) say that introducing the surroundings to children through education on environments at their early age serves as the first step for the children to appreciate environments.

Knowing that environmental education for children is pivotal, it is necessary then to take into consideration a learning approach appropriate with the characteristics of developing it as well as ways of learning for the children by facilitating them to grow both their concerns and awareness towards environments. The approach to learning must be oriented on the development of children's modes of learning exposed through hands-on experience in their daily activities carried out in convenient and fun learning atmosphere.

One of the learning approaches worth considering and promising in accommodating the 
demands is the Research-Based Project Approach. This project approach was proposed in the first place by John Dewey and Killpatrik in the USA in 1920. It assumed that the best time to start learning is when children learn what they think would be their interests (Katz and Chard, 2000). Research-based project approach can be a medium of learning for children to explore objects and things happening in their daily life. Research-based project approach offers an opportunity to children to collaboratively solve environmental problems according to children's learning principles. Kogan (2003) coins that through a project approach, children are able to exercise their skills in solving real problems they encounter in their daily life which are among others environmental problems.

\section{LITERATURE REVIEW}

\subsection{Environmental Education}

\subsubsection{Definition of Environmental Education}

There are various definitions of environmental education as stated by experts and institutions as well. According to UNESCO, environmental education is a learning process that increases people's knowledge and awareness about the environment and associated challenges, develops the necessary skills and expertise to address the challenges, and fosters attitudes, motivations, and commitments to make informed decisions and take responsible action (UNESCO, Tbilisi Declaration, 1978).

Referring to the above mentioned definition, it is clear that environmental education is a process which enables one to gain knowledge, skills, values, and experiences to eventually grasp some concern on environments. Meanwhile, in the Early Childhood Environmental Education Program: Guidelines for Excellence, it is mentioned that environmental education in early childhood is a holistic concept that encompasses knowledge of the natural world as well as emotions, dispositions, and skills. According to Wilson (1994),"environmental education in early childhood includes the development of a sense of wonder; appreciation for the beauty and mystery of the natural world; opportunities to experience the joy of closeness to nature; and respect for other creatures".

Based on the aforementioned statements, early childhood teachers play a very strategic role to facilitate children in developing their sensitiveness on environments. Efforts made to make it happens include integrating environmental education in the school curriculum. Environmental education addressed to children in their early age must be conducted through a concrete approach and has to be integrated the children's daily life. Other than that, the learning process should be in such a way that they find it fun through new findings good for them. This is in line with the guidelines of development and implementation of environmental education for pre-school children as put forward by Wilson (1996) as follows: (a) Begin with simple experiences; (b) Provide excellent positive experiences outdoor; (c) Focus on "experiencing" versus "teaching". (d) Demonstrate a personal interest in and enjoyment of the natural worlds. (e) Model caring and respect for the natural environment.

Principally, early age children tend to develop emotional closeness with things they have familiar with and giving them pleasure. Therefore, to make them find it easy to develop their closeness with the natural environment teacher must provide positive experiences and delights of involving themselves in outdoor activities. Through activities done in an open space, children manage to interact directly with plants, soil, water, air, energy, stone, animal, and various natural happening around them. Those things and the natural events are material of environmental education relevant to daily life.

\subsubsection{The Goal of Environmental Education}

The environmental education, aiming, as committed in the Tbilisi Declaration at the Intergovernmental Conference on Environmental Education taking place in Tbilisi in 1974 and then put into amandements at the UNESCO meeting in the AsiaPacific region, to the followings:

a. To foster awareness of, and concern about economic, social, political and economic interdependence at local, regional, national and international/global levels.

b. To provide every person with opportunities to acquire the knowledge, values, attitudes, commitment and skills needed to protect and improve the environment.

c. To develop and reinforce new patterns of environmentally sensitive behavior among individuals, groups and society as a whole for a sustainable environment.

Environmental education must have an ability to devlop aspects of skills, and attitudes internalized in daily life. In other words, environmental education must have the ability to develop life skills of the children. Instances include the ability to 
separate organic trash from unorganic trash, being used to take care of the plants, caring for pets and, avoiding plants from damage.

Environmental education for early childhood is geard to the development of attitude and behavior aspects of the children to understand the importance of environment for life, caring for and keeping environment leading to positive values integrated in the children's daily life. It has to encourage and provide room for them to take the opportunities to gain basic knowledge, skills, and attitudes enabling them to grow caring, get committed, protect and benefit from environment of life wisely, create new warm patterns of behavior, and have the ability to develop ethics towards environment.

To reach the goal, material as designed in the curriculum and environmental education approach used at educational institution for early childhood must examine closely the principles and different way of learning from older children's way of learning as stated in the Early Childhood Environmental Education Programs: Guidelines for Excellence (2010) running like "Particularly for very young children, environmental education should incorporate exploring woodlands, getting wet feet, climbing rocks, building with sticks, running on grass, running over rocks, following insects, stompuing in puddles, and so forth". Through the activities of a such, children develop direct relationship with natural environment in that they in touch with soil, water, stone, grass. They have courage of holding worms and ants, and collecting garbage. They also have chance to look closer animal cyclus of life like butterflies, frogs, and watching how plants grow. Learning that way, children are exposed to see the values of natural environment and other creatures of God's creation. They would eventually grow a sense of loving at every bit of creation by The Almighty Creator of environments. Those children with great love to environment would feel some juxtaposition with nature and grasp an understanding on relationship between themselves and the nature leading to literate and caring citizens to environment.

\subsection{Research-Based Project Approach}

\subsubsection{Definition}

The project approach is based on the great work of John Dewey (1859-1952), an educationist and philosopher, who views that educataion is a reconstruction of experience. As it goes along, in its development, the project is applied in schools as an approach to learning. The project is an approach implementable in the curriculum of education for early years of children with emphasis on an integrated and children-oriented mode. The integrated learning is not prioritized on the attainment of the aspect of certain development as language or social matter for instance, rather, it accomodates all kinds of various aspects of development so that children have a whole pure of understanding on the topic they are going to learn. As a children-oriented approach, it deals with an adoption of development characteristics, way of learning, superiority, needs, individual children's interest, and social-cultural contexts with where they live.

Katz and Chard (2000) mention that a project is a wide deep study or research or, an investigation on specific topic which can be conducted by children individually, in a small group, or a big one. The process of conducting such study is accommodated with time alloted, interest, and capacities of the children and the institution so that the children are involved actively. Katz and Chard (2000) put forward that incorporating the project into curriculum can enhance children's intellectual development by involving their thoughts through an observation and study on a topic of selected material from the environment and their learning experience. According to Kogan (2003), through the implementation of project approach, kindergarten kids are able to use basic skills to solve real problems they frequently find in their daily life.

The project approach for early childhood is more applicable for a small group in its implementation as compared with an individual mode or a big group. Part of the reason is that through a small group activity, individual capability as well as a small group approach is facilitated optimally. Project approach for young children must be children-centered, and children-teacher collaboration. This way, children learn about specific topics in depth according to their interest, ability and, they would have freedom to choose and do the activity naturally.

Criteria of working in project has their own key point. Henry (1995) puts forward that criteria of working in project as follows: (a) children choose topic of the project, (b) children search for source material, (c) children present final result (usually as a report to be the object of evaluation), (d) children are given freedom to work, (e) activity is conducted in a widened period of time, and (f) teacher play the role of a consultant. 
The topic of the project is taken from the surrounding such as a topic on themselves, their family, schools, plants, cleanliness, animals, and others. Project approach for early chilhood is flexible in terms of the topic chosen, kinds of activity, and the time used can be made in line with the instituion's capacity and the environment where the children live.

\subsubsection{The Purpose of Project Approach}

As an approach to learning, the project has several aims. Katz and Chard (2000) state that the general purpose which is attainable through the project approach for early-age children include the followings: (a) gaining knowledge and skills, (b) enhancing social competence, (c) developing disposition or character, and (d) developing a sense having to do with school experience. By way of direct interaction with environment, children gain concept, idea, fact, and the likes. Project approach also makes it possible for the children to increase their social capability comprising atittude of working in group, skills of initiating, and developing positive relationship with others such as giving some respect, helping each other, sharing, and caring for natural environment.

\subsubsection{Procedures of Research-Based Project Approach}

Implementation of research-based project approach at educational institution for young children must take into consideration topics, kinds of activities, levels of challenge, material and tools adequate with development, groups of children at each stage of age, and time alotted as well. Project topics can refer to the theme in the curriculum, or results of discussion between the children with their teachers. Katz and Chard (2000) put forward that the project approach is conducted through three phases, namely preparation phase, development phase, and culmination phase.

\section{a. Preparation Phase}

Children choose project topic at this phase, sharing knowledge on matters of the topic, asking questions about knowledge they want to gain, designing kinds of activity to be conducted according to the questions asked, and collecting media and learning sources as needed.

b. Development Phase

The development phase is a phase in which children have conducted previous activity designed before. In this phase, exploration takes place and problem solving to answer the questions asked. Efforts made to solve problem are accomplished through direct experience. In this phase, children conduct an investigation through observation, interview with resource person, and conducting simple experiment.

c. Culmination Phase

Culmination is the last phase or a closing activity of the project. In this phase children in their small groups communicate knowledge and skills they gain during the time of studying the topic to each other, teacher, children of other classes, and their parents.

\subsection{Environmental Education through Research-Based Project Approach}

Early ages prove to be precise for the purpose of planting and growing an awareness and values to children in order that they appreciate and car for environment. Flora, fauna, and their usefulness can be introduced to children by asking them to learn through the open space of nature so that they are more motivated to explore various objects and happenings in their surroundings.

Research on project-based learning approach in environmental education involving 39 second year university students pursuing bachelor's degree at the Classroom Teaching Department of Barti University's Faculty of Education conducted by Genc (2015) results in a finding as follows: “....project-based learning had a a positive effect on students' environmental attitudes...". The students say with certainty that the use of project-based learning brings with it a beneficial approach, increasing creativity, encouraging students to conduct research, and providing a permanent way of learning. The students believe that project-based learning helps them identify environment problem in a more straightforward manner and, demands them to do assignment more actively in the process of solving the problem of the environment.

Findings resulted from research by Bartelmay et.al. (2008) on research-based project approach show that project approach makes it possible for enhancing skills of solving problems on the topic of North Carolina Folkive by grade 4 laboratory school of Duke University. Fern's (1998) research on The Research Process through the Project Approach results in finding that project approach motivates kindergarten kids to increase the skill of solving problems in a real situation through a study in depth on the topic of "Paper". 
In the researh-based project, children conduct activities to find a problem, formulate hypothesis, collect data through close examination, interview resource person, do simple experiment, draw conclusion, and communicate the findings. Implementation of environmental education for early childhood through research-based project approach can be realized through the theme of Natural Phenomenon, for instance. Children can conduct a simple project by doing an experiment on floods caused by human not really concerned with the environment like throwing garbage anywhere, and cutting trees in mountains.

The results of research as shown above relate to the positive influence from the project approach on students' attitude about environment and, skills of solving problems by kindergarten kids and elementary school students. Research findings resulted from previous study and experts' school of thought in learning as exsplained above provide strong base of conclusion that research-based project approach can be used to implement environmental education in the setting of education for young children.

\section{REFERENCES}

Bezzina, C., Pace, P. (2006). School improvement, school effectiveness or school development. London: Trentham Books Limited.

The North American Association for Environmental Education. (2010). Early childhood environmental education program: guidelines for excellence. Washington DC: NAAEE Publications. From ww.naaee.org.

Fern, R. (1998). The research process through the project approach. Unpublished Master's Paper.

Genc, M. (2015). The project-based learning approach in environmental education. International Journal: International Research in Geographical and Environmental Education Volume 24, 2015 - Issue 2. From http://dx.doi.org/10.1080/0382046.2014.99316 9.

Henry, J. (1995). Teaching through project: open \& distance learning series. London: Kogan Page.

Katz, L.G \& Chard, S. (2000). Engaging children's minds: the project approach ( $\left.2^{\text {nd }} E d.\right)$. Norwood, New Jersey: Ablex.

Kogan, Y. (2003). A study of bones. Early childhood research \& practice, (1). Retrieved July 3, 2006. From http://ecrp.uiuc.edu/v5n1/kogan.html.
Sutrisno, et al. (2005). Pengenalan lingkungan alam sekitar sebagai sumber belajar anak usia dini. Jakarta: Departemen Pendidikan Nasional, Direktorat Jenderal Pendidikan Tinggi, Direktorat Pembinaan Pendidikan Tenaga Kependidikan dan Ketenagaan Perguruan Tinggi.

UNESCO. (1977). Tbilisi Declaration.

Tilbury, D. (1994). The critical learning years for environmental education. In R.A. Wilson (Ed). Environmental Education at the Early Chilhood Level. Washington, DC: North American Association for Environmental Education. From www.naaee,org.

Wilson, R. A. (1994). Environmental education program for preschool children. Journal of Environmental Education. Washington DC: North American Association for Environmental Education from www.naaee.org.

Wilson, R. A. (1996). Starting early: environmental education during the early childhood years. Clearinghouse for science, mathematics, and environmental education from www.naaee.org. 